\title{
Effects of natural winter browsing and simulated summer browsing by moose on growth and shoot biomass of birch and its associated invertebrate fauna
}

\author{
Michael den Herder ${ }^{1, *}$, Roger Bergström ${ }^{2,3}$, Pekka Niemelä ${ }^{1, \#}$, Kjell Danell ${ }^{3}$ \& \\ Martti Lindgren ${ }^{4}$
}

1) Faculty of Forest Sciences, University of Joensuu, Fl-80101 Joensuu, Finland (*corresponding author's e-mail: Michael.denHerder@joensuu.fi)

2) Forestry Research Institute of Sweden, Uppsala Science Park, SE-751 83 Uppsala, Sweden

3) Department of Wildlife, Fish, and Environmental Sciences, Swedish University of Agricultural Sciences, SE-901 93 Umeå, Sweden

4) Finnish Forest Research Institute, Vantaa Research Unit, Fl-01301 Vantaa, Finland

\# Current address: Department of Biology, Fl-20014 University of Turku, Finland

Received 24 May 2007, revised version received 11 June 2008, accepted 23 Aug. 2008

den Herder, M., Bergström, R., Niemelä, P., Danell, K. \& Lindgren, M. 2009: Effects of natural winter browsing and simulated summer browsing by moose on growth and shoot biomass of birch and its associated invertebrate fauna. - Ann. Zool. Fennici 46: 63-74.

Plant responses to mammalian herbivores can be manifold. Browsing by large mammals such as moose may change plant growth and morphology, which, in turn, will change the food quality and availability for e.g. invertebrate herbivores sharing the same forage plant. Furthermore, the intensity and timing of herbivory may affect plant responses and future herbivore attack. In a field experiment, we tested whether simulated summer browsing and natural winter browsing by moose affects growth and morphology of birch Betula pendula, and whether possible changes had effects on abundance and defoliation by herbivorous invertebrates. The simulated summer browsing treatment was applied in two intensities (50\% and 100\% defoliation of long shoots) during two different periods of the growth season (mid-June and mid-July). Simulated summer browsing delayed the timing of budburst, reduced height and diameter growth and resulted in reduced defoliation by invertebrate herbivores indicating an induced defence. Winter browsing by moose reduced diameter growth, leaf biomass of short shoots but increased height growth, the abundance of aphids and defoliation by insect herbivores. The effects of herbivory on the timing of budburst, leaf biomass of long and short shoots and the abundance of aphids were more pronounced when the birches were both browsed in winter and artificially stripped. The timing of the artificial leaf stripping treatment was important for nearly all tested variables. Concluding, summer and winter browsing by moose can have opposing or additive effects on plant morphology and growth. Therefore, also indirect effects of mammalian herbivory on invertebrate communities feeding on the same plant may differ, depending on the browsing intensity, the season of browsing and even the timing of browsing within the same season. 


\section{Introduction}

The quantitative and qualitative responses of plants to summer and winter browsing by moose may extend well beyond the season of impact (Danell et al. 1994). Leaf-stripping by moose in summer has apparently different effects on tree growth than browsing of shoots in winter. Defoliation during the growing season may directly affect the photosynthetic activity while the responses to winter browsing are delayed until the next growing season. In birch (Betula spp.) winter browsing by moose may decrease the number of shoots for the next winter, but these are generally longer (Bergström \& Danell 1987). Summer browsing has less effect on shoot numbers but may decrease shoots size (Bergström \& Danell 1995). Summer browsing by reindeer has also been shown to reduce shoot size and increase die-back of shoots in two arctic willow species, Salix phylicifolia and Salix glauca (den Herder et al. 2004, 2008). This illustrates the importance of timing of the herbivore attack on tree responses and shows that summer and winter browsing can result in different growth and morphological responses in trees. Furthermore, there are reports that the response of birches to herbivore attack during different periods of the same season can also differ (Danell et al. 2003, Guillet \& Bergström 2006). Trees may, for instance, respond differently after early-season browsing as compared with late-season browsing.

The ecological importance of interactions between different guilds of herbivores has remained relatively little studied, but is an interesting field for future research. For instance, both summer and winter browsing by moose may affect the quality of food for other herbivores feeding on the same forage plant, e.g. insect and other invertebrate herbivores. Moose harvest leaves and shoots as efficient as possible, utilizing large plant modules (Danell et al. 1985). After winter browsing, newly emerging shoots in the following growing season may be more vigorous and the leaves larger than those removed, making the plants more attractive to subsequent herbivore attack (Danell \& Huss-Danell 1985, Price 1991). Furthermore, large modules may be more attractive for ovipositioning female insect herbivores and larvae may survive better
(Roininen et al. 1988, Price 1991). Again, the effects after summer browsing can be quite the opposite. One study on arctic willow found that leaf beetles and galling sawflies were less abundant on shrubs that were browsed by reindeer in summer (den Herder et al. 2004).

Herbivory on leaves may also affect the timing of budburst in the next growing season (Tuomi et al. 1989, Quiring \& McKinnon 1999). The spring emergence of many leaf-feeding insects is closely synchronized with budburst of their host trees. This synchronization is critical for these insects because forage availability decreases rapidly after budburst. As a result, trees where budburst occurs earlier or later may often be less defoliated by herbivorous insects (see e.g. Tuomi et al. 1989, Quiring \& McKinnon 1999, and references therein).

Silver birch (Betula pendula) is an important food plant for moose both during summer and winter. In summer, mainly leaves are stripped off from terminal parts of branches while in winter shoot tips or sometimes whole shoots are browsed (Cederlund et al. 1980). The aims of this study were to examine the effects of natural winter browsing and simulated summer browsing during two phases of the growing period on phenology, growth and leaf biomass of silver birch one year after the browsing event took place. Furthermore, we studied whether browsing-induced phenological and morphological changes in trees have consequences on abundance of herbivorous invertebrates and invertebrate defoliation.

\section{Material and methods}

\section{Study area and birch material}

The study was carried out in 1986-1987 at the tree nursery of the Institute of Forest Improvement in Sävar, 20 km northeast of Umeå in north-

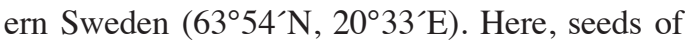
a local provenance of silver birch were collected in 1980 and were sown in a greenhouse in 1981 . In spring 1983 the birches were planted in a field at a distance of $1 \mathrm{~m}$ from each other. The experiment started in 1986 when the trees were on average 1.9 m high (see Bergström \& Danell 1995). 


\section{Experimental design}

Altogether, we used 146 birches in this study. The experimental birches were divided into 8 groups: two control groups and six combinations of different winter browsing and simulated summer browsing treatments at two different intensities and two different treatment dates (Table 1). Each group consisted of 14-30 birches.

\section{Natural winter browsing}

In winter $1985 / 1986$, before the start of the experiment, moose entered the experimental field and browsed some birches. This situation was used for the experiment. In the following spring, we counted the number of moose bites per tree. After the counting we decided that a minimum of 30 bites was needed to include a tree in the group of birches under "high browsing intensity". After this selection procedure, 57 heavily browsed and 89 unbrowsed birches were included in the experiment. Of the selected browsed trees, the number of moose bites per tree was on average about 50 and ranged from 30-110. To protect the birches from further natural browsing, the experimental field was fenced in 1986.

\section{Simulated summer browsing}

Moose leaf stripping was simulated on two occasions during summer 1986. The June treatment was applied during the growing season while the July treatment was applied at the end of the period of shoot elongation. During both occa- sions the leaf stripping treatment was applied in two intensities. The first treatment was applied during 16-17 June and the second treatment was applied during 21-24 July on those trees which had been left untreated before (see also Bergström and Danell (1995) for a more detailed description of the leaf stripping treatment). However, the group of birches which was also exposed to natural winter browsing by moose is not included in their paper. In the tree group with $50 \%$ stripping intensity, the leaves of every second annual long-shoot were stripped. In the $100 \%$ herbivory group, every long shoot was stripped. All treatment started from the lower part of the birches and thereby we guaranteed a random treatment of leading shoots in the $50 \%$ treatment group. Leaves of short shoots are usually not taken by moose and were therefore left on the trees. All leaf material collected during the treatment was dried $\left(40^{\circ} \mathrm{C}\right)$ to constant weight and weighed. The mass of leaves stripped in June and July showed that the simulated defoliation at the $100 \%$ treatment removed twice as much as the $50 \%$ treatment (Bergström \& Danell 1995).

\section{Phenological observations, height growth and diameter growth}

To estimate annual growth, tree height (measured to nearest $0.01 \mathrm{~m}$ from ground level to the upper living part of the top shoot from 1985) and stem diameter (mean of two perpendicular diameters measured in $\mathrm{mm} 0.2 \mathrm{~m}$ above ground) were measured in early June 1986. Height recordings were repeated in September 1986. Stem diameter

Table 1. Number of experimental birches allotted to each group of different treatment combinations.

\begin{tabular}{lccc}
\hline Natural winter browsing intensity & $\begin{array}{c}\text { Artificial leaf-stripping } \\
\text { treatment period }\end{array}$ & $\begin{array}{c}\text { Treatment intensity } \\
\text { (\% leaves stripped) }\end{array}$ & Number of trees $(n)$ \\
\hline No winter browsing & June & 0 & 30 \\
& & 50 & 15 \\
& July & 100 & 15 \\
High winter browsing & & 100 & 15 \\
& June & 100 & 28 \\
& July & 100 & 15 \\
\hline
\end{tabular}


measurements were repeated in September 1986 and September 1987. Phenological observations were made on the tree level on 8 occasions in May 1987 when we estimated the proportion of opened buds in five classes $(0 \%, 25 \%, 50 \%, 75 \%$ and $100 \%$ ).

\section{Leaf biomass}

The experiment was terminated on 20-24 July 1987 when leaves from long shoots and short shoots were collected from all control and treatment trees. Branches were cut and the leaves were removed from each shoot. Leaves from the long shoots and short shoots were kept apart, dried and weighed.

\section{Abundance of herbivorous invertebrates and leaf damage}

During 20-24 July 1987, birch branches chosen at random were quickly pushed into a large net, cut off, stored in a plastic sack and investigated in the laboratory. Here we counted the number of aphids (Homoptera: Aphididae), weevils (Coleoptera: Curculionidae) and leaf-mining moths (Lepidoptera). Insect abundance was calculated as the numbers of individuals per gram of dry birch-leaf mass. Gall mites (Acari: Eriophyidae) were also collected from the sampled branches, but for this group of invertebrates only the weight was measured. Leaves infected by gall mites were collected and mites were scraped off the leaves to collect them. Hereafter their weight was measured. Due to their very small size and large numbers, we did not count individuals but used gall-mite weight per gram of dry birch-leaf mass as an indicator of abundance. Leaves of branches used for expressing insect abundance were dried and weighed as above.

Leaf damage by insect herbivores was surveyed during 20-24 July 1987. We checked every tree and scored the damage as the average damage per leaf on 100 leaves per tree where: 1 $=$ no damage, $2<10 \%, 3=11 \%-50 \%$ and $4 \geq$ $50 \%$ of the leaf area eaten. However, after scoring insect damage it appeared that most leaves belonged to damage class 1 or 2 , and therefore we pooled the damage classes 2-4 and analysed insect damage only as the proportion of leaves damaged by insects.

\section{Statistical analysis}

Height growth and leaf biomass data have been taken from Bergström and Danell (1995) and reanalysed with new objectives: Their experiment only focussed on artificial leaf stripping and did not include a natural winter browsing treatment.

Treatment effects were tested with (multivariate) analysis of variance (GLM procedure in SPSS (2003)) where treatment time (June or July), leaf stripping $(0 \%, 50 \%$ or $100 \%)$ and winter browsing (no browsing, high browsing intensity) were used as fixed factors (Table 1). There were two control groups where $0 \%$ of the leaves were stripped, thus, there is a control for the birches with no winter browsing and a control for the birches subjected to high winter browsing intensity. To test which treatment combination was different from the control group without winter browsing, we used a one-factor model with 8 classification levels (two control groups and six treatment combinations). If the MANOVA or ANOVA revealed an overall significant difference, we used a Tukey B multiple comparison test for testing possible differences between the eight groups of different treatment combinations. We used MANOVA to test variables for which we had a complete data set (biomass data and invertebrate abundance). Since MANOVA can only test complete data sets, we used ANOVA to test variables which had missing data in a few cases (height and diameter growth, leaf burst and leaf damage). The number of aphids and the weight of gall mites per gram of birch-shoot mass were $\ln (x+1)$-transformed to improve normality and homogeneity of variances.

\section{Results}

\section{Phenological observations, height growth and diameter growth}

Natural winter browsing and simulated summer browsing markedly affected phenology and 

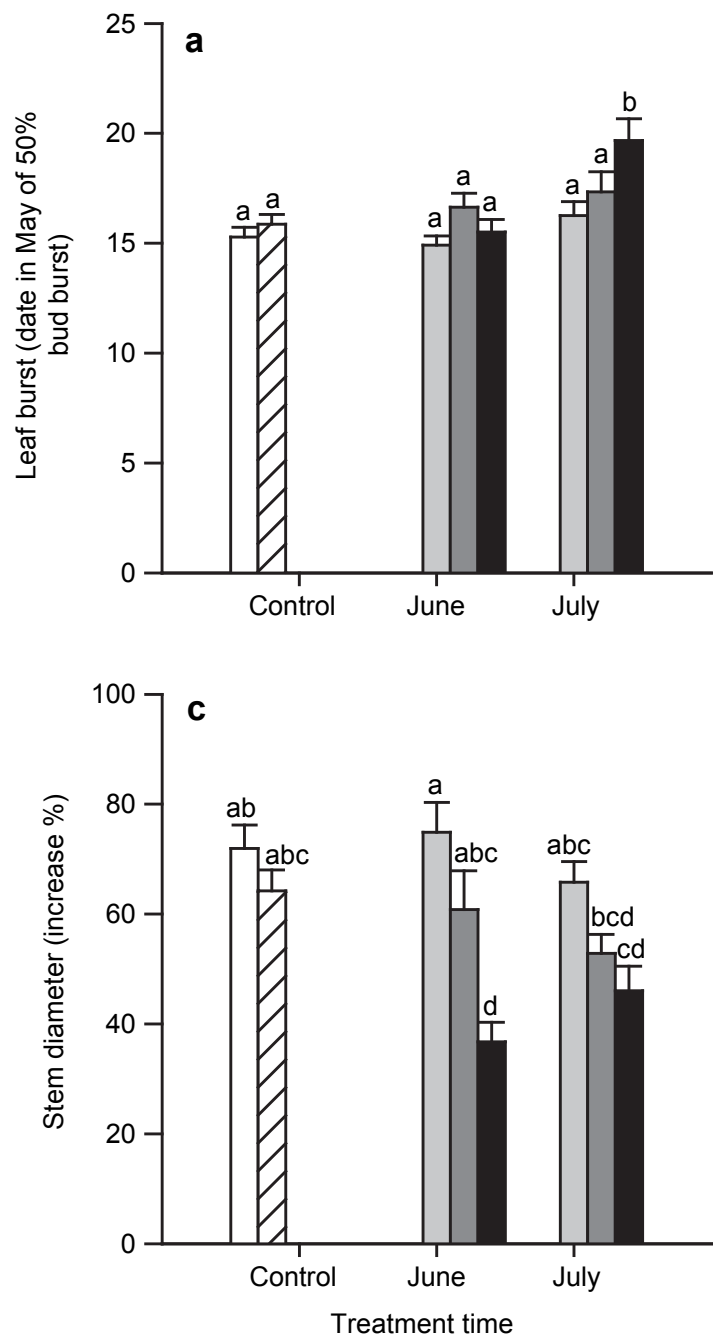

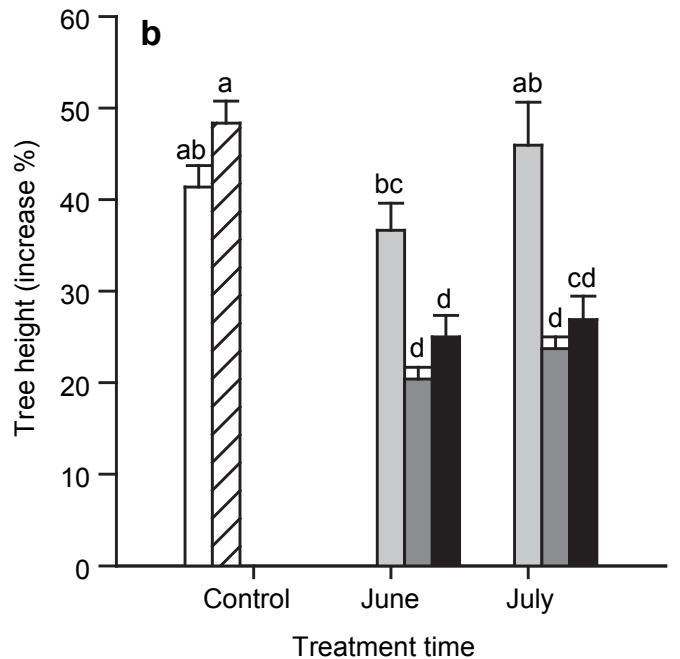

Fig. 1. Effects of moose winter-browsing (WB) and artificial leaf-stripping on (a) the timing of leaf burst (date of $50 \%$ bud burst), (b) height growth, and c) diameter growth of birch one year after the leaf-stripping treatment. There are two control groups: one unbrowsed control (no artificial leaf-stripping, no winter browsing) and a winter-browsed (WB) control (no artificial leaf-stripping, winter browsing). Artificial leaf-stripping was applied on two occasions (June and July) in two different intensities (50\% and $100 \%$ of the number of long shoots stripped). Height growth was measured over the period May-September 1986. Diameter growth was measured over the period June 1986September 1987. Error bars denote one standard error. Different letters (a, b, c, d) above the error bars indicate significant differences between treatment groups (Tukey B multiple comparison test: $P<0.05$ ). Height growth data for birches without winter browsing are redrawn from Bergström and Danell (1995).

growth of the experimental birches (Fig. 1). The date of bud burst one year after the treatment was significantly delayed with increasing artificial leaf-stripping intensity (ANOVA: $F_{1,138}=$ $4.39, P=0.038$ ) and bud burst occurred later in birches where $100 \%$ of the leaves of long shoots had been removed compared with untreated trees (Fig. 1a). The timing of leaf removal also had an effect on the date of bud burst which occurred later on those birches which were treated in July (ANOVA: $F_{1,138}=17.06, P<0.001$ ). Furthermore, there was a significant interaction between the timing of the leaf stripping treatment and natural winter browsing (ANOVA: $F_{1,138}=6.63, P$ $=0.011)$. The date of bud burst was significantly delayed in birches which were both browsed in 
winter and where the leaves were stripped in July (Tukey B: $P<0.05$ ) (Fig. 1a).

Height growth of birch during the treatment season was affected by natural winter browsing (ANOVA: $F_{1,138}=5.40, P=0.022$ ) and leafstripping intensity (ANOVA: $F_{1,138}=40.21, P<$ 0.001 ) (Fig. 1b). The $100 \%$ leaf-stripping treatments reduced height growth by $\sim 50 \%$ of both unbrowsed and winterbrowsed birches (Tukey B: $P<0.05$ ) (Fig. 1b), regardless of whether leaves were artificially stripped in June or July. The 50\% leaf-stripping treatment had no significant effect on height growth.

During the first growing season, the various treatments did not show any significant effect on stem diameter (June-September 1986), although similar trends were found as for height growth (data from Bergström \& Danell 1995). However, after the second growing season (June 1986September 1987), diameter growth of birch was significantly reduced by natural winter browsing (ANOVA: $F_{1,138}=10.62, P=0.001$ ) (Fig. 1c). Furthermore, artificial leaf-stripping also affected diameter growth (ANOVA: $F_{1,138}=6.70$, $P=0.011)$ and this effect was the greatest when $100 \%$ of the leaves of long shoots were removed (Tukey B: $P<0.05$ ).

\section{Leaf biomass}

Simulated summer browsing markedly decreased leaf biomass one year after the trees had been treated (Fig. 2) and these effects were most pronounced when the trees were both subjected to simulated and natural browsing. Also the timing of the artificial leaf-stripping treatment was important. The reduction of leaf mass on long shoots was significant on trees which were both browsed in winter and where $100 \%$ of leaves of the long shoots were artificially removed in July (Tukey B: $P<0.05$ ) (Fig. 2a).

Winter browsing reduced leaf biomass of short shoots (MANOVA: $F_{1,137}=9.60, P=$ 0.002) (Fig. 2b) and the leaf-stripping treatment reduced biomass of the short shoots most when leaves were stripped in July (MANOVA: $F_{1,137}=$ $4.11, P=0.044)$. Trees which were both browsed in winter and artificially stripped produced low leaf mass on short shoots (Tukey B: $P<0.05$ )
(Fig.2b) and the greatest reduction in biomass was measured in the July leaf-stripping treatment group.

The timing of the leaf-stripping treatment was also important for the total leaf biomass as leaf mass was most reduced in the July treatment group (MANOVA: $F_{1,137}=5.71, P=0.018$ ) (Fig. 2c). The reduction of total leaf biomass after winter browsing approached significance (MANOVA: $F_{1,137}=3.75, P=0.055$ ). Birches which were both browsed in winter and artificially stripped produced the lowest total mass of leaves (Tukey B: $P<0.05$ ) (Fig. 2c) and this reduction in mass was especially pronounced in the July treatment group.

\section{Abundance of herbivorous invertebrates and leaf damage}

The abundance of aphids living on birch was higher on trees which were stripped in July suggesting that the timing of the leaf-stripping (MANOVA: $F_{1,109}=4.06, P=0.046$ ) affects aphids. Furthermore, aphid abundance was higher on birches which were browsed in winter (MANOVA: $F_{1,109}=5.41, P=0.022$ ) (Fig. 3a). The highest aphid abundance was observed on trees which were both browsed in winter and artificially stripped (Tukey B: $P<0.05$ ). The abundance of Curculionidae, Lepidoptera and Eriophyidae was not significantly affected by any of the natural or simulated browsing treatments (Fig. 3b-d).

Defoliation by insect herbivores was higher on birches which were browsed in winter (ANOVA: $F_{1,137}=10.51, P=0.001$ ). Furthermore, there was a significant interaction between leaf-stripping intensity and the timing of leafstripping (ANOVA: $F_{1,137}=6.23, P=0.014$ ). Unbrowsed birches, where $100 \%$ of the leaves were removed in June, were less defoliated by insect herbivores as compared with other treatment groups (Tukey B: $P<0.05$ ) (Fig. 3e).

\section{Discussion}

Natural winter browsing and simulated summer browsing on birch resulted in changes in the 

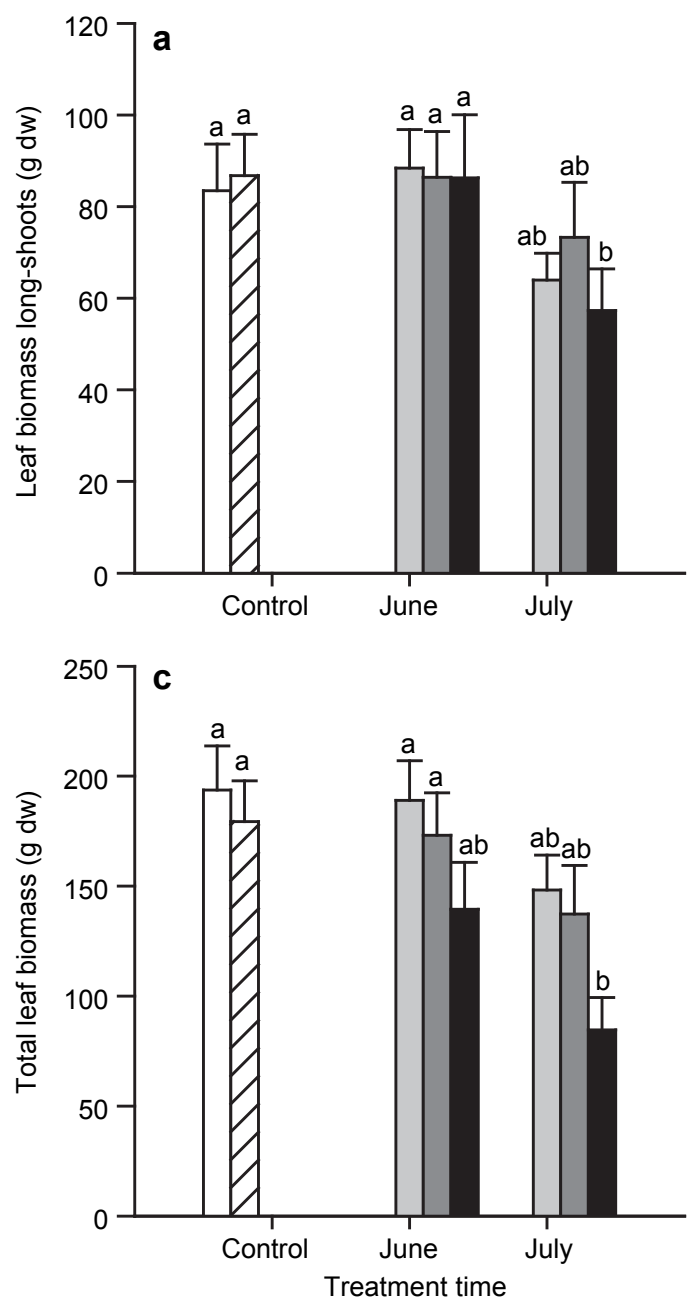

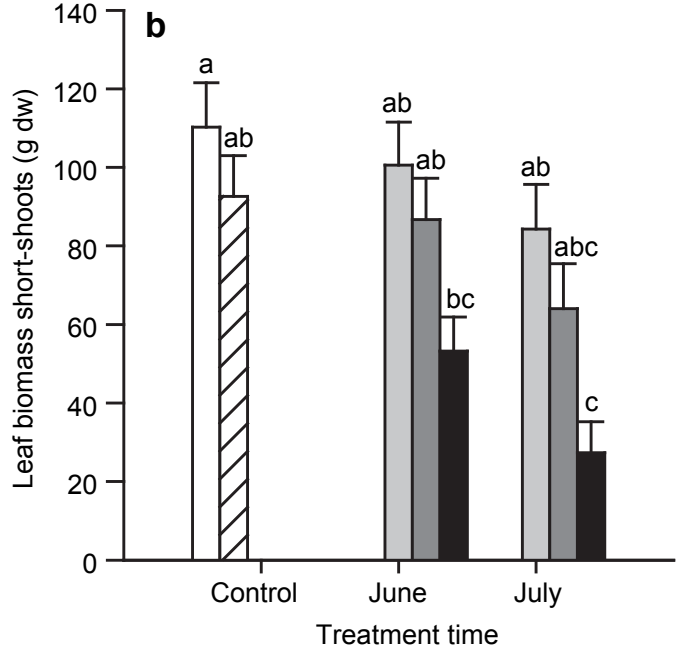

Fig. 2. Effects of moose winter-browsing (WB) and artificial leaf-stripping on (a) biomass of long shoots, (b) short shoots, and (c) total biomass of annual shoots of birch one year after the leaf-stripping treatment. There are two control groups: one unbrowsed control (no artificial leaf-stripping, no winter browsing) and a winter-browsed (WB) control (no artificial leaf-stripping, winter browsing). Artificial leaf-stripping was applied on two occasions (June and July) in two different intensities (50\% and $100 \%$ of the number of long shoots stripped). Error bars denote one standard error. Different letters (a, b, c) above the error bars indicate significant differences between treatment groups (Tukey B multiple comparison test: $P<0.05$ ). Leaf biomass data for birches without winter browsing are redrawn from Bergström and Danell (1995).

date of budburst, tree growth, leaf biomass, abundance of aphids living on birch and insect damage to the leaves. The changes on both leaf and shoot biomass were already evident during the season of experimental leaf stripping (Bergström \& Danell 1995) and the present study shows that tree responses to browsing last even one year later.

\section{Phenological observations, height growth and diameter growth}

Budburst was significantly delayed by almost four days in birches which were both browsed in winter and which were $100 \%$ stripped in July. The 50\% leaf-stripping treatment did not seem to delay budburst and there was also no difference in the date of budburst between the June and July treatment. This contradicts the 

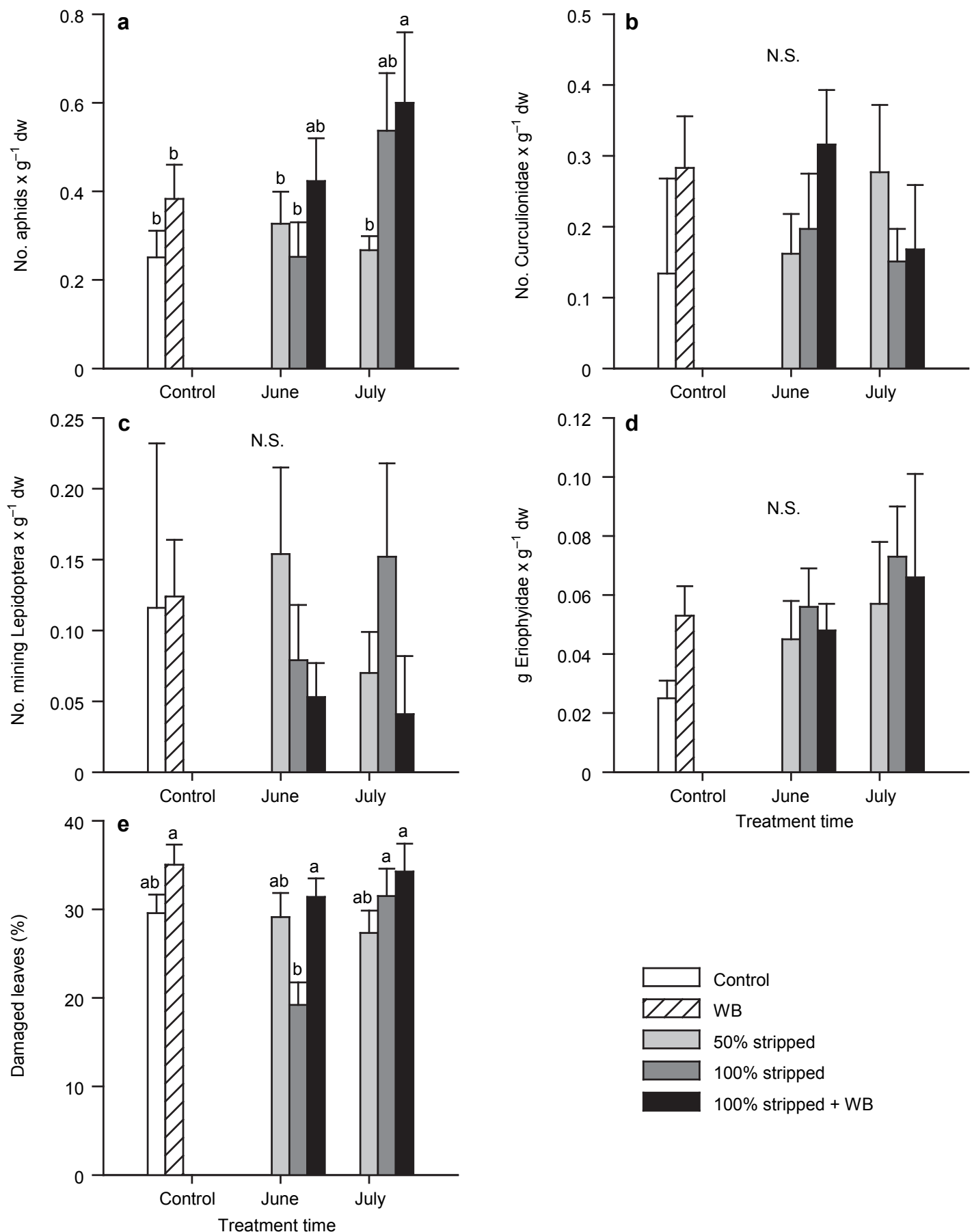

Fig. 3. Effects of moose winter-browsing and artificial leaf-stripping on the abundance of (a) aphids, (b) Curculionidae, (c) mining Lepidoptera, and (d) Eriophyidae living on birch one year after the leaf-stripping treatment. (e) Effects of moose winter-browsing and artificial leaf-stripping on the amount of defoliation by herbivorous insects. There are two control groups: one unbrowsed control (no artificial leaf-stripping, no winter browsing) and a winterbrowsed (WB) control (no artificial leaf-stripping, winter browsing). Artificial leaf-stripping was applied on two occasions (June and July) in two different intensities (50\% and $100 \%$ of the number of long shoots stripped). Error bars denote one standard error. Different letters $(a, b)$ above the error bars indicate significant differences between treatment groups (Tukey B multiple comparison test: $P<0.05$ ). N.S. indicates that there was no significant effect. 
results of Tuomi et al. (1989) who suggested that especially early-season defoliation may cause delayed budbreak. Tuomi et al. (1989) discussed two explanations for defoliation-induced delays in budburst. Delayed budburst may be an adaptive, induced defensive response of the tree to reduce future herbivory by early-season defoliators by escaping in time, or: a physiological consequence through reduced resources resulting from previous defoliations (resource depletion hypothesis). Tuomi et al. (1989) suggested that since the final leaf size was reduced by leaf stripping in their experiment, late budburst must be a result of a reduction in the resource pool available for bud and leaf development. As birch buds develop a year before leafburst, previous defoliation may affect buds during their development. On early defoliated branches, developing buds are deprived of photoassimilates that would otherwise have been translocated to them from the leaves. One reason why we did not find any effect of early-season defoliation on budburst could be that in our trees a refoliation took place after the June leaf-stripping treatment (Bergström \& Danell 1995). Thus, even buds on early defoliated trees still received some photoassimilates for bud development. However, our results present convincing evidence which supports the resource depletion hypothesis as suggested by Tuomi et al. (1989), since budburst was delayed most in those trees which were both artificially stripped and browsed in winter by moose.

Height growth during the season of impact was significantly lower on heavily defoliated trees as was already observed in a study simulating summer browsing by Bergström and Danell (1995). Our study shows that the same reduction of height growth occurs on trees which have been both previously artificially defoliated and browsed in winter. Trees which were not artificially defoliated but only naturally browsed in winter actually showed increased height growth compared to the unbrowsed control (Fig. 1b). Apparently simulated summer browsing and natural winter browsing has different effects on height growth of trees. Reduced height growth after simulated summer browsing could partly be a result of tips of leading shoots being removed during stripping and partly of a generally slower height growth of the leading top shoots (Berg- ström \& Danell 1995). After winter browsing, larger and heavier long shoots have been recorded in previous studies (Danell et al. 1985, Bergström \& Danell 1987, Persson et al. 2006). Combined summer and winter browsing seems to have similar effects on shoot size as summer browsing alone as is shown by the results of this study. The stem diameter growth from spring 1986 to autumn 1987 was also reduced by defoliation in a similar pattern as height growth. The same pattern was earlier observed from spring to autumn 1986 on the same trees by Bergström and Danell (1995) although the difference they observed was not significant. Apparently, defoliation still has a pronounced effect on diameter growth one year after impact.

One shortcoming in this study was that moose was able to browse the trees before they were fenced. Thus, the winter-browsed trees are not completely chosen randomly but moose may have chosen plants selectively. This may have somehow confounded the results from the winter-browsing treatment. In other words, some of the changes caused by winter-browsing may reflect that moose prefer to feed on that type of tree. To test if moose selected trees on the basis of their growth rate, we compared the stem diameter data for all treatment groups from early June 1986, which were taken before the onset of the growing season. Between most groups there was no difference. However, there was a small difference in stem diameter between the unbrowsed control $(19.9 \mathrm{~mm} \pm$ S.D $5.0 \mathrm{~mm})$ and the winterbrowsed trees with $100 \%$ leave stripping in June $(25.7 \mathrm{~mm} \pm$ S.D. $4.3 \mathrm{~mm})$ (ANOVA: $F_{7,138}=$ $2.90, P=0.007)$. Nevertheless, after the next growing season, height, diameter growth and leaf biomass were much reduced by summer and winter-browsing, even though moose may have selected trees with a higher growth rate. If we would have chosen our winter-browsed birches completely random, which is of course recommendable, the negative effects of winter browsing could have been even more dramatic.

\section{Leaf biomass}

Biomass of long-shoot leaves, short-shoot leaves and total leaf biomass was significantly lower on 
trees which were both artificially defoliated and browsed by moose. Earlier studies on the same trees by Bergström and Danell (1995) which included only artificially defoliated trees, showed that defoliation did not affect leaf biomass of long shoots but leaf biomass of short shoots was significantly reduced by the $100 \%$ leaf-stripping treatment (see also Fig. 2b). Although mean shoot mass of individual long shoots was already reduced in the study by Bergström and Danell (1995), yet there was no effect noticed on total (long-)shoot mass. However, they observed a change in the percentage of branched shoots. Comparison of the study by Bergström and Danell (1995) and the present study shows that combined summer and winter browsing may result in a more pronounced reduction of leaf mass on both long and short shoots.

From our data is seems that the trees give priority to leaf production on long shoots in order to repair the damage after defoliation or winter browsing. Leaf biomass on short shoots was reduced to a greater extend as compared with leaf biomass on long shoots. In the year preceding this study, Bergström and Danell (1995) noticed that $81 \%$ of the shoots on the trees stripped $100 \%$ in July had dried to some degree, leading to increased "twig die-back". Damage to tips of long shoots may cause more basal buds to develop into long shoots, instead of short shoots, as has been shown by Danell et al. (1985). After summer browsing, these shoots may generally be shorter as compared with unbrowsed controls. After winter browsing, the number of shoots may be less, but the shoots can be longer.

The timing of the artificial leaf-stripping treatment also had an effect on leaf production of both long and short shoots. Late-season defoliation led to a greater reduction in leaf mass compared to early-season defoliation. Similar results were observed in studies on Salix viminalis, a fast-growing willow which is often grown in northern Europe for the production of bioenergy (Guillet \& Bergström 2006).

In our birches, we observed an exact compensation (sensu Belsky 1986) in leaf mass on long and short shoots after simulated summer browsing or natural winter browsing. However, the trees undercompensated when simulated summer browsing and natural winter browsing were combined. Apart from overcompensation at the level of the whole above-ground biomass at low browsing intensities, Guillet and Bergström (2006), similarly, did not observe evidence for overcompensation after simulated summer and winter browsing in willow cloned for bioenergy, one of the fastest-growing deciduous trees in northern Europe. Generally, they observed exact compensation after winter browsing and undercompensation after simulated summer browsing. Willow may produce longer (but fewer) shoots after browsing (Roininen et al. 1997) but the total biomass is rarely higher in browsed plants as compared with unbrowsed plants (but see Paige \& Whitham 1987).

\section{Abundance of herbivorous invertebrates and leaf damage}

We observed increased abundance of aphids on birches which were both artificially stripped and browsed by moose in winter. The highest abundance was found on browsed trees which were stripped late in the growing season. Budburst occurred later in this group of birches and these trees also showed the lowest height and diameter growth and had the lowest leaf biomass on short and long shoots. In other words, their general "vigour" was reduced. Our results seem to contradict the "plant vigour hypothesis" which suggests that herbivores prefer to attack vigorously growing plants or plant modules (Price 1991). In our study artificial leaf-stripping combined with winter browsing clearly resulted in reduced plant vigour and Bergström and Danell (1995) already noticed a reduction in shoot diameter and mass. In our study, aphids seem to prefer "stressed plants" as predicted by the "plant stress hypothesis" (White 1969, 1976, 1984, Mattson \& Haack 1987a, 1987b). This hypothesis proposes that physiologically stressed plants become more susceptible to herbivores because of reduced protein synthesis and increased amino acids in their tissues, resulting in more nutritious food. Rhoades (1979) suggested that stressed plants are less able to produce defensive chemicals what makes them, together with a possible improved nutritional value, more attractive to herbivores.

Damage by leaf-feeding insects was signifi- 
cantly lower on unbrowsed birches which were $100 \%$ defoliated in June. This indicates that earlyseason defoliation triggered an induced defence in our experimental birches while late-season defoliation did not. Earlier studies on mountain birch also reported an induced defence after early-season defoliation (Haukioja \& Niemelä 1979). However, the induced response of leaves of mountain birch ceased before the middle of August, i.e. at the time when leaves had completed their growth. This may explain why we did not find a late-season induced response in our experimental birches; at the time of the lateseason defoliation treatment (late July), growth had completed. In the mountain birches studied by Haukioja and Niemelä (1979), growth of leaves (and possibly induced defence) continued until later in the season since the growth season starts so much later in their study area which is about $600 \mathrm{~km}$ further north. An obvious explanation for the cessation of induced defence after late season defoliation is that leaves are not so much worth protecting since they will fall in any case in September. An alternative explanation may be that late season defoliators are more adapted against increased chemical defences.

A remarkable contrast with the unbrowsed birches was that in winter browsed birches which were also $100 \%$ defoliated, no evidence for induced defence was noted. This again conforms to the "plant stress hypothesis" which states that stressed plants are less able to produce defensive chemicals (Rhoades 1979). Probably combined summer and winter browsing reduced plant vigour so much that the plants' nutrients reserves were depleted and thereby their ability to mobilize nutrients for their defence.

Earlier studies examining the interactions between herbivorous mammals and insects have shown that plant responses induced by moose (Danell \& Huss-Danell 1985, Roininen et al. 1997), hare (Roininen et al. 1994) and beaver (Martinsen et al. 1998) can increase the abundance of insect herbivores and resulted in more leaf damage. Studies revealing negative indirect effects of mammalian herbivory on insects are rare. One study on Viburnum dilatum showed that browsing by sika deer increased leaf hardness which resulted in lower leaf damage by insect herbivores (Shimazaki \& Miyashita 2002).
Another study on arctic willow S. phylicifolia showed reduced abundance of leaf beetles and gall-inducing sawflies after summer browsing by reindeer (den Herder et al. 2004). In this study, reindeer browsing resulted in fewer and shorter shoots which reduced forage availability for leaf beetles and the number of shoots suitable for ovipositioning for galling sawflies. The studies which reported positive effects of mammalian herbivory on insect herbivores have in common that they are all dealing with winter browsing or browsing of shoots/stems by mammals, which is similar to pruning by humans. Contrary, those studies reporting negative interactions examined browsing of leaves in summer. In a meta-analysis, reviewing the effect of herbivory in 68 studies conducted on 52 woody plants species and 19 insect herbivore species, Nykänen and Koricheva (2004) also noted that the effects of changes in plants on herbivore performance clearly depended on the type and timing of damage. In general, both natural and simulated defoliation reduced herbivore performance (induced resistance), while simulated mammal browsing in general increased pupal weight, insect growth and their survival. Apparently summer and winter browsing not only has opposing effect on the morphological and growth responses of plants, but also indirect effects on insect communities feeding on the same plant may differ.

\section{Acknowledgements}

We thank the Institute of Forest Improvement at Sävar for providing facilities. M.d.H. was financially supported by a grant from the Academy of Finland to Pekka Niemelä (Finnish Centre of Excellence Programme 2002-2005, project no. 64308), the Finnish Society of Forest Research (Suomen Metsätieteellinen Seura) and the Emil Aaltonen Foundation.

\section{References}

Belsky, A. J. 1986: Does herbivory benefit plants? A review of the evidence. - American Naturalist 127: 870-892.

Bergström, R. \& Danell, K. 1987: Effects of simulated winter browsing by moose on morphology and biomass of two birch species. - Journal of Ecology 75: 533-544.

Bergström, R. \& Danell, K. 1995: Effects of simulated summer browsing by moose on leaf and shoot biomass 
of birch, Betula pendula. - Oikos 72: 132-138.

Cederlund, G., Ljungqvist, H., Markgren, G. \& Stålfelt, F. 1980: Foods of moose and roe deer at Grimsö in central Sweden. Results of rumen content analysis. - Swedish Wildlife Research 11: 169-247.

Danell, K. \& Huss-Danell, K. 1985: Feeding by insects and hares on birches earlier affected by moose browsing. - Oikos 44: 75-81.

Danell, K., Huss-Danell, K. \& Bergström, R. 1985: Interactions between browsing moose and two species of birch in Sweden. - Ecology 66: 1867-1878.

Danell, K., Bergström, R. \& Edenius, L. 1994: Effects of large mammalian browsers on architecture, biomass and nutrients of woody plants. - Journal of Mammalogy 75: 833-844.

Danell, K., Bergström, R., Edenius, L. \& Ericson, G. 2003: Ungulates as drivers of tree population dynamics at module and genet levels. - Forest Ecology and Management 181: 67-76.

den Herder, M., Virtanen, R. \& Roininen, H. 2004: Effects of reindeer browsing on tundra willow and its associated insect herbivores. - Journal of Applied Ecology 41: 870-879.

den Herder, M., Virtanen, R. \& Roininen, H. 2008: Reindeer herbivory reduces willow growth and grouse forage in a forest-tundra ecotone. - Basic and Applied Ecology 9: 324-331.

Guillet, C. \& Bergström, R. 2006: Compensatory growth of fast-growing willow (Salix) coppice in response to simulated large herbivore browsing. - Oikos 113: 33-42.

Haukioja, E. \& Niemelä, P. 1979: Birch leaves as a resource for herbivores: seasonal occurrence of increased resistance in foliage after mechanical damage of adjacent leaves. - Oecologia 39: 151-159.

Martinsen, G. D., Driebe, E. M. \& Whitham, T. G. 1998: Indirect interactions mediated by changing plant chemistry: beaver browsing benefits beetles. - Ecology 79: 192-200

Mattson, W. J. \& Haack, R. A. 1987a: The role of drought stress in provoking outbreaks of phytophagous insects. - In: Barbosa, P. \& Schultz, J. C. (eds.), Insect outbreaks: 365-407. Academic Press, New York.

Mattson, W. J. \& Haack, R. A. 1987b: The role of drought in outbreaks of plant-eating insects. - Bioscience 37: $110-118$.

Nykänen, H. \& Koricheva, J. 2004. Damage-induced changes in woody plants and their effects on insect herbivore performance: a meta-analysis. - Oikos 104: 247-268.
Paige, K. N. \& Whitham, T. G. 1987: Overcompensation in response to mammalian herbivory: the advantage of being eaten. - American Naturalist 129: 407-416.

Persson, I.-L., Danell, K. \& Bergström, R. 2005: Different moose densities and accompanied changes in tree morphology and browse production. - Ecological Applications 15: 1296-1305.

Price, P. W. 1991: The plant vigor hypothesis and herbivore attack. - Oikos 62: 244-251.

Quiring, D. T. \& McKinnon, M. L. 1999: Why does early season herbivory affect subsequent budburst? - Ecology 80: 1724-1735.

Rhoades, D. F. 1979: Evolution of plant chemical defense against herbivores. - In: Rosenthal, G. A. \& Janzen, D. H. (eds.), Herbivores: their interaction with secondary plant metabolites: 3-54. Academic Press New York.

Roininen, H., Price, P. W. \& Tahvanainen, J. 1988: Field test of resource regulation by the bud-galling sawfly, Euura mucronata, on Salix cinerea. - Holarctic Ecology 11: 136-139.

Roininen, H., Price, P. W. \& Tahvanainen, J. 1994: Does the willow bud galler, Euura mucronata, benefit from hare browsing on its host plant? - In: Price, P. W., Mattson, W. J. \& Barachikov, Y. N. (eds.), The ecology, physiology and evolution of gall-forming insects: 12-26. USDA Forest Service General Technical Report NC-174, Washington.

Roininen, H., Price, P. W. \& Bryant, J. P. 1997: Response of galling insects to natural browsing by mammals in Alaska. - Oikos 80: 481-486.

Shimazaki, A. \& Miyashita, T. 2002: Dear browsing reduces leaf damage by herbivorous insects through an induced response of the host plant. - Ecological Research 17: 527-533.

SPSS 2003: SPSS advanced models 12.0. Users guide. - SPSS Inc. Chicago, IL.

Tuomi, J., Niemelä, P., Jussila, I., Vuorisalo, T. \& Jormalainen, V. 1989: Delayed budbreak: a defensive response of mountain birch to early-season defoliation? - Oikos 54: 87-91.

White, T. C. R. 1969: An index to measure weather-induced stress of trees associated with outbreaks of psyllids in Australia. - Ecology 50: 905-909.

White, T. C. R. 1976: Weather, food and plaques of locusts. - Oecologia 22: 119-134.

White, T. C. R. 1984: The abundance of invertebrate herbivores in relation to the availability of nitrogen in stressed food plants. - Oecologia 63: 90-105. 